\title{
Advances in Paleopathology: from phylogenetic analyses to ancient medical literature - An Editorial Forward
}

Organized by Drs Sheila Maria Ferraz Mendonça de Souza, Luiz Fernando Ferreira, Adauto Araújo, and Karl Jan Reinhard, this excellent Paleopathology Special Issue of Memórias do Instituto Oswaldo Cruz was distributed in 20 articles written by 50 scientists from six countries: Argentina, Brazil, Canada, France, Hungary, and United States. The papers cover an extensive field of knowledge from phylogenetic analyses of a DNA sequences through paleogenetic, paleopathology, paleoentomology, paleoepidemiology, paleoecology, paleosociology to ancient medical texts up to modern reading problems.

For a better visualization of the whole text of this Special Issue, we are hight-lighting two or three phrases of the summary of each article to emphasize it importance.

Article 1 by Katharina Dittmar et al. - "One of the crucial steps of authentication of a DNA sequences is phylogenetic consistency. Amplied sequences should fit into the phylogenetic framework of their supposed origin. In this paper some fundamental problems of phylogenetic analysis and interpretation of aDNA datasets are discussed. Suggestion for character sampling and treatment of missing date are made".

Article 2 by Anderson Nonato do Rosario Marinho et al. - "The present paper discusses mtDNA and taphonomy of human remains from Moa, Beirada, and Zé Espinho sambaquis of Saquarema, state of Rio de Janeiro, Brazil. Preservation of microscopic lamellae and DNA is not related to the macroscopic integrity of the bones. Results here suggest that the preservation of amplifiable DNA fragments may have relation to the preservation of the lamellar arrangement as indicated by optical microscopic examination (polarized light)".

Article 3 by Jennifer Raff et al. - "Vertebral lesions have been the main evidence for infection by the Mycobacterium tuberculosis complex (MTC) in paleopathology. This study tests the hypothesis that rib lesions can serve as a useful marker for MTC infection within the Mississippian Schild skeletal collection from WestCentral Illinois. Ribs from 221 adults and juveniles were examined, and affected individuals were tested for TB (tuberculosis) complex infection. The results support the use of ribs lesions as a marker for TB infection".

Article 4 by Martín H Fugassa et al. - "Three techiniques to extract parasite remains from archeological were tested. The aim was not improve the sensitivity of recommended paleoparasitological techniques applied in archaelogical remains. Sediment collected from the pelvic girdle of a human body found in Cabo Virgenes, Santa Cruz, Argentina, associated to a Spanish settlement founded in 1584 known as Nombre de Jesús, was used to search for parasites. Positive results were obtained only with the modified technique, resulting in the finding of Trichuris trichiura eggs in the sediment".

Article 5 by Christine White et al. - "This paper examines the synergism among diet, disease, and ecology at two related coastal Maya sites in Belize for the Postclassic and Historic periods (1350-1650 AD), which immediately follow the Classic period collapse. There are apparent differences in whole diets or degree of carnivory between individuals with lesions indicative of anemia and those without, but those with lesions appear to have consumed significantly more $\mathrm{C}_{4}$ foods and protein from lower trophic levels".

Article 6 by Gino Chaves da Rocha et al. - "Human occupation for several centuries was recorded in the archaelogical layers of "Place d'Armees", Namur, Belgium. Preventive archaeological excavations were carried out between 1966/1997 and seven historical strata were observed, from Gallo-Roman period up to Modern Times. Soil samples from cesspools, latrines, and structures-like were studied and revealed intestinal parasite eggs in the different archaeological contexts".

Article 7 by Matthieu Le Bailly et al. - "During the excavations of the XIX century Meadowlark cemetery (Manhattan, Kansas, US), samples sediments were taken from five skeletons, and analyzed to detected intestinal parasite. No helminth eggs were found, but immunological ELISA tests for Entamoeba histolytica were positive in three samples. Amoebiasis could have been a severe disease in the past, especially where poor sanitary conditions prevailed".

Article 8 by José Dilermando Andrade Filho et al. - "Phlebotominae includes some vector species, mainly that of leishmaniases, with a very old host-parasite relationship. Some species fossils of this subfamily have been recently described and this paper presents the description of a new sand fly Pintomya (Pifanomyia) paleotowsendi sp. nov. in amber.

Article 9 by Alicia Kay Wilbur and Jane Ellen Buikstra - "Tuberculosis (TB) is an infectious disease that continues to take is toll on human lives. Paleopathological research indicates that it has been a significant cause of death among humans for at least five thousand years. In this paper, we discuss the pre-Columbian TB controversy, and then use research from biological and biomedical sciences to help inform paleopathological and archaeological studies of this ubiquitous disease that plagued our ancient forbears".

Article 10 by Antónia Marcsik et al. - "The analysis of the skeletons of past human populations provides some of the best biological data regarding the history of significant diseases such as tuberculosis. The purpose of this study is to present the pathological alterations of the bones in this disease deriving from the ancient time of the territory of the Hungarian Great Plain on the basis of the earlier references and new cases". 
Article 11 by Jerome C Rose - "The Egyptian Pharaoh Akhenaten initiated workship of a single god and estabilished a new capital city (Tell Amarna) that was built and occupied only once from 1350-1330 BCE. The royal tombs have long been known and studied, but the location of graves for the common inhabitants has been an archaeological puzzle for more than 50 years. Life for the common residents of Amarna appears to not have been as good as innitially postulated.

Article 12 by Rachel W Wentz et al. - "Assessment of intrapopulation human health provides information concerning social structure, division of labor, and lifestyle. Differential health among the sexes can provide clues to social roles, resource acquisition and status within prehistoric populations. Over 168 well-preserved individuals were excavated, providing a glimpse into life during Florida's Archaic. Through the application of the Western Hemisphere Health Index, we find that males within the group experienced better overall health than females".

Article 13 by Maria Araya Rosado and Jessica Vernacchio-Wilson - "The Museo de La Serena, IV Region, Chile has collections of skeletal remains representing the agricultural Diaguita people of 500 years ago excavated in the 1980s from the sites Peñuelas 21 and 24, Chile's semiarid north. The objectives of this communication are to: establish demographic patterns of the skeletal samples and identify and diagnose skeletal paleopathologies via photography and radiographs. The high frequency of carious lesions indicates a diet that emphasized carbohydrates".

Article 14 by Ricardo Aníbal Guichón et al. - "The objective of this paper is to present the first steps into the study of health in southern Patagonia during pre and post Native-European contact. Thus, our work has a double purpose. First, to discuss characteristics and relevance of human bone records of southern Patagonia, in order to study health in a population context. Second, to show some new lines of information, which include paleoparasitology, nutritional paleopathologies, and the study of lifestyles from human remains".

Article 15 by Patricia M Lambert - "The skeletal remains of 17 people buried in the Eaton Ferry Cemetery in northern North Carolina provide a means of examining health and infectious disease experience in the XIX century South. Skeletal indices used to characterize health and disease in the Eaton Ferry sample include dental caries, antemortem toot loss, enamel hypoplasia, porotic hyperostosis, periosteal lesions, lytic lesions, and stature. Specific diseases identified in the sample include tuberculosis and congenital syphilis".

Article 16 by Sheila Mendonça de Souza et al. - "Syphilis is a sexually or congenitally transmitted infectious disease with an impact on the health of human populations that has undergone important cycles in different countries an periods of history. In Portugal, although there are various written records of the infection in the last centuries, there are rare references to it in archeological findings. The current study describes a probable case of congenital syphilis in an 18-month-old girl buried in the Church of the Sacrament in Lisbon. Her body, dating to the XVIII century".

Article 17 by László Szathmáry and antónia Marcsik - "The sample examined consists of 19 skulls with symbolic trephinations and 86 skulls without trepanations dated from the X century. Skulls were all excavated in the Great Hungarian Plain in the Carpathian Basin, which was occupied by the Hungarian conquerors at the end of the IX century. The variations of 12 cranial dimensions of the trephined skulls were investigated and compared to the skulls without trepanations after perfoming a discriminant analysis".

Article 18 by Andrea Lessa et al. - "The sample consists of 226 skulls from the Atacameño cemetery of Coyo Oriente (639-910 DC), associated with the Tiwanaku period. The authors analyzed signs of acute trauma typically associated with violence, and the results were $12 \%$ of men and $9.9 \%$ of women displaying any type of lesion related to violence. In males, concentration of these non-lethal lesions in the nasal region (10.4\%) as opposed to a random distribution over the entire skull (1.6\%) suggests that the blows were struck during rituals".

Article 19 by Veronica Wesolowski - "Because of the relationship with subsistence, dental caries is a central issue in paleopathological research. Usually, comparisons between caries prevalence exhibited in different skeletal series are made. Dietary variation is the most common explanation for cavities prevalence. The aim of this paper is to verify if it is possible to compare caries prevalence reported on papers for archaeological skeletal series. Only very few implicated factors other than diet as a contributor to caries development".

Article 20 by Maria Carlota Rosa - "The word tradition has a very specific meaning in linguistics: the passing down of a text, which may have been completed or corrected by different copyists at different times, when the concept of authorship was not the same as it is today. When reading an ancient text the word tradition must be in the reader's mind. This work deals with one of the first printed medical texts in Portuguese, the Regimento proueytoso contra ha pestenença and draws a parallel between it and two related texts".

As one can see by the above high-lighted articles, this special Issue of Memórias do Instituto Oswaldo Cruz on "Paleopathology" is one extensive brain storning exercise of research in the paleoecoepidemiology by emininents experts from Europe, North and South America, who are publishing a very broad and beautiful studies done in different countries of both continents. As Scientific Editior of Memórias I am very happy and proud to host those articles in our journal. I am sure they will be an international success for the authors and for their readers. 